\title{
Sur la technique de tissage du tissu aux paons. Une soierie losangée à bandes de samit façonné
}

Daniël De Jonghe et Chris Verhecken-Lammens

\section{(2) OpenEdition}

Édition électronique

URL : https://journals.openedition.org/tc/335

DOI : $10.4000 /$ tc.335

ISSN : 1952-420X

Éditeur

Éditions de l'EHESS

\section{Édition imprimée}

Date de publication : 1 janvier 2000

ISSN : 0248-6016

\section{Référence électronique}

Daniël De Jonghe et Chris Verhecken-Lammens, « Sur la technique de tissage du tissu aux paons. Une soierie losangée à bandes de samit façonné », Techniques \& Culture [En ligne], $34 \mid 2000$, mis en ligne le 26 octobre 2005, consulté le 29 septembre 2022. URL : http://journals.openedition.org/tc/335 ; DOI : https://doi.org/10.4000/tc.335

Ce document a été généré automatiquement le 29 septembre 2022.

Tous droits réservés 
Sur la technique de tissage du tissu aux paons. Une soierie losangée à bandes de samit façonné

Daniël De Jonghe et Chris Verhecken-Lammens 